\title{
GARANTISMO E LITERATURA: A LIÇÃO DE LEONARDO SCIASCIA SOBRE O PAPEL DOS PRINCÍPIOS NA CONSTRUÇÃO DAS DECISÕES
}

\author{
André Karam Trindade ${ }^{1}$ \\ Marilin Soares Sperandio ${ }^{2}$
}

\section{Resumo}

O presente ensaio aborda uma das grandes questões relativas à decisão judicial: o que significa "decidir por princípio"? Para tanto, assumindo a premissa de que muitos fenômenos e problemas jurídicos são melhor representados através das narrativas literárias do que em grande parte dos manuais jurídicos, a problemática é formulada a partir da novela Portas abertas, de Leonardo Sciascia, cujo protagonista é um magistrado que enfrenta o regime fascista ao afastar a pena de morte durante o polêmico caso, na década de 30, de um triplo homicídio, julgado pelo tribunal do júri em Palermo. Desse modo, com base nos pressupostos teóricos dos estudos do Direito na Literatura (law in literature) e na noção de "modelos de juiz", proposta originalmente por François Ost, pretende-se analisar a representação do pequeno juize discutir a função dos princípios na construção das decisões judiciais.

Palavras-chave: Direito na Literatura. Modelos de juiz. Leonardo Sciascia. Decisão judicial. Princípios.

\section{INTRODUÇÃO}

Desde o início dos anos 80, François Ost $(1983,1991,1993,2009)$ tem utilizado a noção de modelos de juiz - inclusive recorrendo a personagens mitológicas, às quais são associadas algumas figuras - para analisar $\mathrm{e}$ discutir as funções desempenhadas pelos membros do Poder Judiciário. Sua inovadora proposta não decorre de uma crise resultante da ausência de referências, mas sim do seu excesso, em razão da heterogeneidade e complexidade do campo judicial. Assim, Ost propõe a construção de seus conhecidos modelos - Júpiter, Hércules e Hermes - precisamente para aqueles que, sob a toga, parecem impossível de se modelar 3 .

Como se sabe, os trabalhos de Ost impulsionaram, de maneira decisiva, os estudos em Direito e Literatura no Brasil - sobretudo a partir da tradução de Raconter la loi. Aux sources de l'imaginaire juridique, no

\footnotetext{
${ }^{1}$ Doutor em Teoria e Filosofia do Direito (Roma Tre/Itália). Professor dos Programas de Pós-Graduação em Direito da Faculdade Meridional (IMED/RS) e da Faculdade Guanambi (FG/BA). Coordenador do KATHÁRSIS - Centro de Estudos em Direito e Literatura da IMED. Presidente da Rede Brasileira Direito e Literatura (RDL). Editor-chefe da ANAMORPHOSIS Revista Internacional de Direito e Literatura. E-mail: andre.karam@imed.edu.br.

${ }^{2}$ Mestranda em Direito (IMED). Membro do KATHÁRSIS - Centro de Estudos em Direito e Literatura da IMED. Membro Efetivo da Rede Brasileira Direito e Literatura (RDL).E-mail: mss.marilin@gmail.com.
} 
ano de 2005 -, em especial o desenvolvimento da abordagem conhecida como Direito na Literatura, a partir da qual se investiga de que modo os fenômenos jurídicos e as grandes questões ligadas à justiça são representadas pelas narrativas literárias ao longo da História (MITTICA, 2015; POSNER, 2009; TRINDADE e GUBERT, 2008).

Na verdade, a literatura exsurge como um verdadeiro repositório de fontes para a reflexão crítica do direito. Além disso, por meio de suas ficções ocorre o registro histórico dos valores de um determinado lugar ou época, na medida em que suas representações do poder, da lei e da justiça, por exemplo, também conformam o imaginário coletivo e social (OST, 2005; TALAVERA, 2006).

Isso ocorre, especialmente, nas grandes obras de literatura. Os clássicos são aqueles livros a respeito dos quais, dificilmente, se ouve estou lendo, mas quase sempre estou relendo. Aliás, essa é a primeira das quinze definições de clássico formuladas por Ítalo Calvino (1991). Outra delas, a terceira, diz que os clássicos são livros que exercem uma influência particular quando se impõe como inesquecíveis e também quando se ocultam nas dobras da memória, mimetizando-se como inconsciente coletivo ou individual. É por essa e outras razões que também se afirma que um clássico jamais se esgota. Ele sempre tem algo a nos dizer. Ele atravessa o tempo e, portanto, é sempre atual.

A título ilustrativo, no que diz respeito ao protagonismo judicial, é possível identificar os mais diversos modelos de juiz na literatura ocidental: "Palas Atenea”, de Ésquilo, na tragédia Orestéia (458 a. C); “Filocleon”, de Aristófanes, na peça As vespas (422 a.C.); "juiz da beira”, de Gil Vicente, na farsa O juiz da beira (1525); o "juiz Bridoye”, de François Rabelais, no romance Gargantua e Pantagruel(1532); "Pórcia”, de William Shakespare, na peça O mercador de Veneza (1605); "Ângelo", também de William Shakespare, na peça Medida por medida (1608); “o juiz de paz”, de Martins Pena, na peça O juiz de paz da roça (1833); o “juiz Ivan Ilitch”, de Liev Tolstoi, na novela A morte de Ivan Ilicht (1886); o "juiz Solaguren”, de Pedro Prado, na novela Un juez rural(1924); "o Juiz”, de Franz Kafka, no livro O processo (1925); “Barão de Andergast", de Jakob Wassermann, no romance $O$ processo Maurizius (1928); o “juiz Komives”, de Sandor Marai, na novela Divórcio em Buda (1935); o "juiz Azdak", de Bertolt Brecht, na peça O círculo de giz caucasiano (1944); "Hathorfe", de Arthur Miller, na obra As bruxas de Salém (1953); "o magistrado”, de John-Maxwell Coetzee, no romance À espera dos bárbaros (1980); o “juiz Cosme”, de Camilo José Cela, na obra O assassinato do perdedor (1994); "o juiz-presidente”, de Bernhard Schlink, no romance O leitor (1995); o "nosso juiz", de Marcelo Carneiro da Cunha, no romance O nosso juiz (2004); e, mais recentemente, a “juíza Fiona”, de Ian McEwan, no romance A balada de Adam Henry (2014)4.

\footnotetext{
${ }^{3}$ Registre-se, por oportuna, a contundente crítica formulada por Lenio Streck (2011) acerca dos modelos mitológicos utilizados pelo renomado jurista belga.

${ }^{4}$ Tal levantamento foi elaborado durante a execução do projeto de pesquisa "O direito na literatura: a representação dos juízes nas narrativas literárias”, desenvolvido pelo KATHÁRSIS - Centro de Estudos em Direito e Literatura, vinculado ao Programa de PósGraduação em Direito da IMED, no biênio 2012/2014, que já resultou na seguinte produção bibliográfica (STRECK e TRINDADE, 2015; TRINDADE e ROSENFIELD, 2015; TRINDADE e CALGARO, 205; TRINDADE, 2014).
} 
Neste ensaio, portanto, partindo dos pressupostos teóricos e metodológicos do estudo do Direito na Literatura, aliados à noção de modelos de juiz - formulada, originalmente, por Ost -, pretende-se analisar a representação literária do juiz ${ }^{5}$ e, de modo geral, o papel conferido aos princípios na construção das decisões judiciais, a partir da novela Portas abertas ${ }^{6}$, escrita em 1987, pelo célebre Leonardo Sciascia, que envolve o julgamento de um crime cuja sanção é, em tese, a pena de morte. A recomendação da leitura, cumpre referir, veio de Luigi Ferrajoli. Daí a ponte entre garantismo e literatura, a ser explicitada ao final deste artigo.

\section{O MESTRE DE RACALMUTO: ENTRE A TRADIÇÃO FASCISTA E A CULTURA ILUMINISTA}

Leonardo Sciascia nasceu em 1921, no vilarejo siciliano de Racalmuto, em Agrigento, Itália. Ensaísta, romancista, professor e político, foi um importante intelectual italiano, que se dedicou a denunciar em tons pastéis a bruta realidade de seu tempo. Em seus enredos, o mestre de Racalmuto, como era conhecido, retratou a Sicília como metáfora do mundo?.

Em 1935, ainda adolescente, mudou-se com sua família para Caltanisseta, onde frequentou o Istituto Magistrale IX Maggio. Lá conheceu Vitaliano Bracanti, um professor e escritor iluminista que teve influência fundamental em sua vida e obra. Em 1941, Siascia retornou a Racalmuto, onde permaneceu até 1948. Nesse período, começou a trabalhar como professor do primário e casou-se com Maria Andronico, companheira de toda a sua vida (ONOFRI, 2004).

Sciascia cursou a Faculdade de Educação, na Università Degli Studi di Messina, preparando-se para se dedicar ao magistério. Tal experiência permitiu-lhe conhecer uma realidade impossível de suportar, mas que precisava ser enfrentada pelos jovens alunos de Racalmuto. Foi nesse exato momento que, como forma de oposição, diante da impossibilidade de fazer algo realmente relevante, nasceu a vontade de escrever como forma de denúncia ${ }^{8}$.

\footnotetext{
${ }^{5}$ Sobre as personagens jurídicas no universo literário, com destaque para a figura do juiz, ver a enciclopédia de Alberto Sousa Lamy (2003), além dos estudos de Jorge Fábrega Ponde (2013) e de Amalia AMaya (2016).

${ }^{6}$ Muito embora a baixa qualidade da tradução, utilizou-se neste ensaio a edição brasileira do livro (SCIASCIA, 1990), sobre o qual, especificamente, houve a gravação de um programa de televisão, Direito \& Literatura, exibido pela TV Justiça, em 2011, apresentado por Lenio Streck. O vídeo encontra-se disponível em: <https://www.youtube.com/watch?v=aPKWVN8A3KE>. Acesso em: 10/12/2015.

${ }^{7}$ Em entrevista concedida à jornalista francesa Marcelle Padovani, Sciascia (1979) revelou que o enredo da grande maioria de suas obras se passa na Sicília (ou, então, em lugares fictícios que se parecem como ela) porque as marcas deixadas pelas guerras e pelos regimes totalitários formaram um mundo sombrio que não se restringia à Itália, mas a todo o Continente. Evidentemente que escolher a Sićlila como metáfora do mundo também se deve ao fato de que Sciascia era apaixonado por sua terra natal.

${ }^{8}$ Para Sciascia, o escritor serve somente quando ajuda a viver na verdade: "me convenci que a única forma de verdade é aquela da arte. $\mathrm{O}$ escritor desvela a verdade decifrando a realidade e trazendo à superfície. Em certo sentido, simplificando-a” (SCIASCIA, 1979, p. 84-87). No mesmo sentido, cumpre referir a importante tese de doutorado de VIVA, Samantha Agata Viva (2011, p. 28). vol.09, nº. 04, Rio de Janeiro, 2016.pp. 2124-2149 2126
} 
Nesse mesmo sentido, aliás, Scarpinato entende que, de um modo geral, a obra de Sciascia caracteriza-se por colocar em cena a obscenidade do poder.

A palavra obsceno deriva do latim $o b$ scenum e significa literalmente fora de cena. $\mathrm{O}$ verdadeiro poder é aquele que se exercita no obsceno, isto é, fora de cena, na trama oculta dos acordos pessoais transversais, nos corredores e nos bastidores dos palácios [...] Na sua origem, o verbo imponere significa far portare peso e, na linguagem eclesiástica, ingannare imponendo una credenza. A tarefa que Sciascia atribui a si mesmo como intelectual e como escritor é, precisamente, aquela de desmascarar as imposturas do poder em todas as suas declinações: poder político, econômico, eclesiástico, mafioso. Essas imposturas impedem que se compreenda a realidade, que se veja a vida nua, tornando os cidadãos meros marionetes (SCAPRINATO, 2014, p. 218-219).

Na verdade, o mestre de Racalmuto fez parte de uma geração de escritores que começou a se ocupar, ao mesmo tempo, tanto da literatura como da política, alcançando sucesso em ambos. Assim como outros renomados escritores - Calvino, Pasolini e Camilleri -, enfrentou a dificuldade de expressar em palavras o áspero sabor da vida e de transformar em obra literária aquele trágico cenário que era o seu próprio mundo (CALVINO, 2006, p. 3).

Sua produção literária não se limita a nenhum estilo específico. Ao longo de praticamente quatro décadas, Sciascia publicou poesias, fábulas, crônicas, ensaios, contos, novelas e romances. No entanto, como se sabe, o romance policial - ou giallo, como dizem os italianos ${ }^{9}$ - foi sua marca maior. Muito embora não tenha sido o precursor de tal gênero (TODOROV, 2006, p. 93-103), Sciascia promoveu uma renovação ao trazer à tona as contradições da realidade e levá-las para dentro de suas narrativas (DIONíSIO, 2013, p. 78).

Ao contrário dos demais escritores desse gênero, Sciascia desilude os leitores que aguardam a solução do caso e o triunfo da verdade ao final do livro. Como esclarece Scarpinato (2014, p. 224), nos romances de Sciascia, o investigador alcança a verdade graças ao uso da razão, mas essa verdade percebida no plano individual não pode ser a verdade coletiva e processual: "não pode ser porque é a própria polis, a própria sociedade da qual o poder é expressão e espelho, que a impede [...] para que a verdade se manifeste em nível institucional, para que assuma uma forma legal, é preciso a vontade e a colaboração de toda a polis".

Em sua vida, Sciascia não teve um grande envolvimento com o mundo jurídico. Isso não o impediu, porém, de trabalhar uma série de questões vinculadas à justiça em grande parte de suas obras ${ }^{10}$. A começar pelo primeiro de seus escritos - Le favole della ditatura (1950) -, no qual retrata, através de uma perspectiva crítica e provocativa, o comportamento sociedade diante de um sistema de leis e de hierarquias durante o período da

\footnotetext{
${ }^{9} \mathrm{Na}$ Itália o gênero literário romance policial é conhecido como giallo que, na tradução para o português significa "amarelo". Isso ocorreu porque a editora Mondadori, em 1929, criou uma coleção chamada I libri Gialli, cunhando o termo a partir da cor escolhida para ilustrar as capas dos romances policiais. A tradução dos livros no Brasil ficou por conta da editora Globo, de Porto Alegre, que publicou cerca de 160 títulos de romances policiais, entre 1931 e 1956, por meio da alusiva "Coleção Amarela" (SANTURBANO, 2013, p. 50).

${ }^{10}$ Como afirma Finuoli (2014, p. 257-258): "aquilo que surpreende o jurista na leitura de seus romances é que o escritor Leonardo Sciascia conheça o direito".
} 
ditadura fascista. Na mesma época, ainda, passou a exercer atividades jornalísticas, colaborando com periódicos de diferentes regiões da Itália até o final de sua vida.

Uma das mais populares de suas obras é Il giorno della civetta, publicada em 1961, cujo enigmático e metafórico título foi pensado a partir de uma frase de Shakespeare, como explica o próprio Sciascia (2012, p. XXX). Tal narrativa - romanzo di mafia per eccelenza, segundo Mendola (2014, p. 198) - baseia-se em fatos reais e tematiza as dificuldades de se investigar uma série de assassinatos em um contexto social dominado pela máfia. Com sua publicação, Sciascia ficou conhecido por sua audácia, pois foi o primeiro que ousou denunciar o sistema num período em que ninguém havia se atrevido a falar do envolvimento da máfia nas relações sociais e políticas vivenciadas na Itália ${ }^{11}$.

Como adverte Coluccello, é impossível analisar a imagem da máfia sem falar sobre as obras de Sciascia ou, no mínimo, remeter à leitura de Il giorno della civeta, em particular. Sua descrição de tal fenômeno não se limitou a um ataque dirigido à máfia, mas também conteve uma ácida crítica à ausência do Estado, que se tornou fiador e cúmplice da expansão das organizações mafiosas, principalmente na Sicília. Trata-se, sem dúvida, do mais vendido de seus livros, sendo o primeiro a ser traduzido em língua estrangeira e também a se tornar filme, além de servir de roteiro para diversas adaptações teatrais (COLUCCELLO, 2015, p. 178-179).

Esse importante livro de Sciascia evidencia uma tese conhecida por todos aqueles que se dedicam ao estudo das relações entre Direito e Literatura (MARÍ, 1998; AGUIAR E SILVA, 2001; CALVO GONZÁLEZ, 2012; VESPAZIANI, 2015): "antes das investigações judiciárias, antes das comissões parlamentares, antes do direito e da lei, está a literatura a contar a verdade. Está a literatura a iluminar a realidade, obrigando a política italiana a se interessar pelos fatos da máfia. Está a literatura a favorecer a tomada de consciência sobre os problemas da justiça" (FINUOLI, 2014, p. 257). O caso jurídico é, portanto, apenas um artifício empregado para enfrentar grandes questões, que envolvem os mais profundos e complexos problemas ligados ao ideal de justiça e que transcendem sua solução.

Outras narrativas, sobretudo as novelas policiais, também são conhecidas por abordar temas como a corrupção, a violência, as relações políticas e sociais, a (in)justiça etc. Suas personagens frequentemente possuem um significado cultural que denuncia o trágico conflito que enfrentam, e, ao descobrirem como resolver seus problemas, são impedidas de fazê-lo em razão das forças ocultas do poder. Vejamos. A ciascuno il suo (1966) é considerado uma obra-prima da literatura italiana. Relata a investigação de um duplo homicídio que assustou um pequeno vilarejo siciliano. Trata-se de uma obra que transforma um relato policial em história, questionando até onde podem chegar a violência e a falsidade humanas. Em Il contesto (1971), o protagonista é o inspetor Rogas, que defende rigorosamente a aplicação da lei e dos princípios democráticos. Contudo, ao investigar uma série de

${ }^{11}$ A edição escolástica, de 1972, foi alvo de grande polêmica em 1993 (MENDOLA, 2014, p. 210-214). 
assassinatos de juízes, ele percebe sua impotência diante do crime organizado. A narrativa traz a lume como o poder dominante da máfia é responsável pela assepsia dos princípios e ideologias de questões políticas, desvelando o poder obsceno, obscuro, que protagoniza a história italiana e que corresponde à traição dos valores sancionados pela Constituição de 1948 (SCARPINATO, 2014, p. 227). Na mesma linha, 1912+1 diz respeito a um rumoroso caso judicial que abalou a Itália no início do século XX. Com um tiro certeiro, a condessa Maria Tiepolo mata o ajudante de seu marido, o capitão Carlo Oggioni, no ano que os supersticiosos evitavam pronunciar, preferindo chamá-lo $1912+1$. As investigações apontam a defesa da honra e a suspeita de uma paixão secreta como explicação para o homicídio. Todavia, o processo assume inesperados e absurdos contornos, movimentando a opinião pública. Mais de mil cartas anônimas chegam ao tribunal reivindicando justiça a qualquer preço.

Como se vê, grande parte da obra de Sciascia concentra-se sobre o tema da justiça. Isso porque - e, aqui, está a grandeza intelectual do autor, conforme Scarpinato (2014, p. 223) - ele "compreende aquilo que não havia sido plenamente compreendido pelos escritores da sua geração, à exceção de pouquíssimos como Pier Paolo Pasolini, e que será esquecido, depois dele, pelas gerações sucessivas". Dito de outro modo, Sciascia antecipa uma das anomalias que marca, muito particularmente, a história italiana: o problema da relação entre poder e justiça. Essa é a fonte de todos os demais problemas ${ }^{12}$.

É por isso que, em todos os seus romances voltados à criminalidade do poder, Sciascia narra sempre a história falência a impossibilidade de justiça quando se está diante dos crimes do poder. Como refere Scarpinato (2014, p. 224), "em uma sociedade injusta não existe a possibilidade de uma justiça justa. É possível apenas uma justiça que seja espelho da realidade social: uma justiça forte com os fracose fraca com os fortes’.

Como diz o próprio Sciascia:

Tudo está ligado, para mim, ao problema da justiça, com o qual se envolve aquele da liberdade, da dignidade humana, do respeito entre homem e homem. Um problema que se resume na escritura, que na escritura encontra tormento ou redenção. Eu diria que o documento me fascina - escritura da tormenta - enquanto entidade na escritura, na minha escritura, redentora (SCIASCIA, 2012, p. XIII).

Após vinte e cinco anos escrevendo, Sciascia aposenta-se do magistério e decide investir na sua carreira política e candidata-se às eleições comunais de 1975, como independente nas listas do Partido Comunista Italiano (PCI), sendo eleito como o segundo mais votado. Ocorre que, desgostoso com a política, abandonou o conselho municipal em 1977, decidindo voltar a se dedicar somente à literatura. No entanto, em 1979, Sciascia retorna a atuar no âmbito político, dessa vez pelo Partido Radical (PR), sendo eleito tanto para a Câmara dos Deputados como também para o Parlamento Europeu, optando por exercer apenas o cargo de deputado, que ocupou até

\footnotetext{
${ }^{12}$ Como aduz Scarpinato (2014, p. 223): "Sciascia é consciente de que toda a história italiana vem marcada por uma criminalidade plurissecular do poder que se manifesta sobre três aspectos: o massacre e o homicídio como instrumentos normais de luta política; o método mafioso como método ordinário de exercício do poder; a predação e a corrupção sistêmica".
} 
1983 (MACALUSO, 2010).

Entre suas últimas batalhas no campo da política estão a defesa de Enzo Tortora, um amigo que sofrera um erro judiciário, e o apoio dado a Adriano Sofri, acusado em 1988 do homicídio de Luigi Calabresi, para que antes se elucidasse quem assassinou, no final da década de 60, o anarquista Giuseppe Pinelli.

Morreu um ano depois, em 1989, na cidade de Palermo. Em sua homenagem, no ano de 1993, em Milano, fundou-se a associação Amici di Leonardo Sciascia.

\section{PORTAS ABERTAS E O DILEMA DO PEQUENO JUIZ}

Portas abertas é uma das últimas novelas de Sciascia, havendo sido publicada em 1987. A narrativa - que reúne elementos reais ${ }^{13}$ e fictícios ${ }^{14}$ - é um verdadeiro convite à reflexão sobre questões que, desde sempre, ocupam o centro das discussões e que atravessam a história do pensamento jurídico: a pena de morte, a segurança pública e a decisão judicial ${ }^{15}$.

Apesar de o livro ter obtido notoriedade no cenário internacional ao ser adaptado para o cinema - o filme Open doors (no Brasil, As portas da justiça), de Giane Amelio e Angelo Rizzi, recebeu o prêmio de Filme do Ano, concedido pela Academia de Cinema Europeu, em 1990 -, ele é pouco conhecido e trabalhado no Brasil, tendo passado praticamente desapercebido pela comunidade dos juristas, à exceção de Jacinto Nelson de Miranda Coutinho e Lenio Streck.

\footnotetext{
${ }^{13} \mathrm{Na}$ verdade, segundo esclarecem os arquivos do jornal italiano La Repubblica, o juiz palermitano chamava-se Salvatore Petrone. Ele nasceu em 1887, em Racalmuto - cidade natal também de Sciascia -, o que aumenta a chance de terem se conhecido. Ingressou na magistratura em 1912 e era reconhecido por sua substancial superioridade intelectual e moral. De todo modo, sua carreira não foi propriamente brilhante, tendo de aguardar até 1935, quando já havia 48 anos, para ser promovido. Em 1937, quando então integrava a Corte de assise di Palermo, chegou às suas mãos o caso do triplo homicídio imputado a Giuseppe Bruno. À época, a sanção cominada pelo Código de Rocco em caso de crimes separadamente puníveis com prisão perpétua era a pena de morte. O processo tramitou rapidamente. Na ocasião do julgamento, apesar da pressão hierárquica e da expectativa social, o júri lançou uma sentença condenatória à prisão perpétua, sob o fundamento de que os três homicídios constituam um único crime, sendo praticados em continuidade delitiva. A reação foi imediata. Ao tomarem conhecimento da posição sustentada em juízo por Salvatore Petrone, o irmão de uma das vítimas escreve a Mussolini, que rapidamente determinou a investigação contra o magistrado. O presidente da Corte confirmou que, durante a reunião do conselho de sentença, a aplicação da pena capital restou frustrada em razão da ação sútil e capciosa do juiz Salvatore Petrone, à qual aderiu a maioria dos jurados, de maneira que prevaleceu sua tese. O presidente da Corte propôs uma sanção disciplinar de advertência ao juiz Salvatore Petrone em razão do absurdo jurídico por ele promovido no processo e, igualmente, porque havia sido pouco respeitoso com o presidente enquanto sustentava sua posição, usando um tom de voz muito alto. No entanto, sabiamente, o Ministro da Justiça, Arrigo Solmi, exclui a hipótese de ilícito disciplinar, pois eventual erro judiciário, mesmo que gravíssimo, não poderia ser sancionado se cometido por magistrado de boa-fé no exercício de suas funções. Assim, o Conselho Superior - órgão interno ao Ministério da Justiça - limitou-se a sugerir que Salvatore Petrone fosse transferido para outa sede, sob a condição de que isso o satisfizesse. Obviamente que ele escolheu permanecer em Palermo. Após todos os retardos possíveis, ele foi promovido à Corte de Cassação (BERTONI, 1990). Na mesma linha, o trabalho de Gaetano Savatteri (2005, p. 195).

${ }^{14}$ Como destaca Marino (2014, p. 254), o protagonista de Portas abertas remete a um livro de 1591, intitulado Avvertimenti di un Cristiano, de Argisto Giuffredi, um poeta palermitano que, dois séculos antes de Beccaria, lutava contra a tortura e a pena de morte.

${ }^{15}$ A associação Amici di Leonardo Sciascia oferece um interessantíssimo Percurso Didático, organizado por Francesco Bonfanti, professor de letras, sobre a obra Portas abertas, pensado para os docentes e destinado aos estudantes do ensino médio. O material, vol.09, no. 04, Rio de Janeiro, 2016.pp. 2124-2149 2130
} 
Nesse contexto, a fim de evitar qualquer prejuízo ao leitor, a novela pode ser contada, resumidamente, da seguinte maneira. No ano de 1937, no auge do regime fascista, o cometimento de um triplo homicídio assusta a comunidade de Palermo, na Sicília. O protagonista da trama não possui nome, sendo referido pelo narrador apenas como o juiz a latere ${ }^{16}$ - ou o pequeno juiz - que, na condição de membro da Corte d'Assise, será um dos responsáveis por julgar o acusado desse crime hediondo. Em suas mãos está a sorte de um homem que, premeditadamente, havia assassinado três pessoas em curto espaço de tempo. As vítimas haviam sido sua esposa; o homem que ocupara seu lugar na repartição de onde ele havia sido demitido; e por fim, o homem que, no vértice daquela repartição, determinara sua demissão. A máquina judiciária pressiona para que o desfecho do processo seja a condenação à pena de morte, principalmente porque uma das vítimas fora um renomado advogado membro do partido fascista. No entanto, apesar de todas as circunstâncias, o pequeno juiz está determinado a não aplicar a pena capital por uma questão de princípio. E assim o faz, sendo apoiado por outros membros do conselho de sentença, mesmo que isso pudesse lhe custar muito caro e, provavelmente, a decisão viesse a ser reformada na instância superior.

Observa-se, portanto, que a narrativa suscita questões complexas e profundas, abarcando (a) a problemática do paradigma jurídico de matriz técnico-positivista que orientou o regime fascista; (b) o solapamento do direito diante da maximização da Política; (c) a invasão do Estado na intimidade da vida privada; (d) a manipulação dos meios de difusão de informação; (e) o discurso demagógico do controle da criminalidade por meio da imposição da pena de morte; e, ainda, (f) a resistência dos princípios face ao totalitarismo ${ }^{17}$.

Isso fica evidente, desde logo, no diálogo de abertura da narrativa, travado entre o pequeno juiz e o procurador geral, quando discutem o caso do tríplice homicídio de forma bastante cautelosa. O procurador geral conhecia a posição do pequeno juiz contrária à pena de morte. O pequeno juiz, por sua vez, tinha consciência de que o procurador geral queria dissuadi-lo de seus ideais. Ambos já haviam conversado sobre isso há dez anos, quando a pena capital havia sido restaurada no sistema jurídico italiano, conforme recorda o procurador geral, na posse de uma antiga revista que tratava do assunto:

cuja qualidade é notável, contém uma série de propostas de trabalho, atividades e exercícios. Disponível em: http://www.amicisciascia.it/images/scuola/Percorso_didattico_Porte_aperte.pdf.

${ }^{16}$ Cumpre esclarecer que o júri italiano é diferente do brasileiro, pois adota a modalidade do escabinato. Trata-se de uma sistemática que funciona da seguinte forma: no primeiro grau há a corte d’assise (assistência), limitada à competência de crimes graves. Sua composição é formada por um colegiado que conta com a participação de dois juízes togados, um deles é o giudice a latere (o juiz assistente) e o outro, o juiz-presidente do conselho de sentença, que é complementado com outros seis juízes leigos. As sentenças prolatadas nessa corte poderão ser reformadas pela Corte d'assise d'Appello, cujo colegiado também é composto por dois juízes de carreira e seis juízes populares (GRILLI, 2009, p. 149).

${ }^{17}$ Um exemplo disso foi a realização do Seminario Internazionale sulla Morte come Pena in Leonardo Sciascia, organizado pela associação Amici di Leonardo Sciascia, no dia 8 de fevereiro de 1997, em Firenze, cujos atos foam publicados sob a organização de vol.09, n. 04, Rio de Janeiro, 2016. pp. 2124-2149 2131 


\begin{abstract}
- Não me lembro com que argumento o senhor o refutava; lembro-me, entretanto do tom, extremamente irritado. Posso até concordar que o exórdio é um tanto irritante: "A restauração da pena de morte na Itália" - leu - "exigida pela consciência nacional, invocada pela Câmara dos Deputados, sancionada pelo Governo do Rei, satisfaz um antigo anseio da ciência italiana", o que não deixa de ser um pouco demasiado, admito... Mas quanto às considerações tratadas pelo artigo, eu estava e estou completamente de acordo. - Esperou que o juiz dissesse alguma coisa. Desiludido, continuou: - Acredite ou não, eu pelo apreço que tenho pelo senhor e, com sua licença, por um sentimento de benevolência, de amizade... - Fico agradecido - disse o juiz (SCIASCIA, 1990, p. 14).
\end{abstract}

Um discurso que, para o pequeno juiz, era enfadonho. Inicialmente, com vestes de conselho, mas que, aos poucos, vai tomando os contornos de uma velada ameaça:

- [...] desejo apenas convidá-lo - continuou o procurador - a uma reflexão sobre este processo que automaticamente chega ao Tribunal do qual o senhor participa: e antes de mais nada, pergunto se não seria conveniente, não havendo mudado as opiniões quanto à pena de morte, renunciar à tarefa ou, como posso dizer?, encontrar de comum acordo com o presidente do Tribunal de Recursos, a maneira mais oportuna, menos prejudicial, para a sua carreira: até agora bastante brilhante, devo dizer... - Eu, como já disse e continuo repetindo, estou plenamente de acordo com a tese de sua excelência Rocco - nunca deixava de atribuir aos que lhe faziam jus o título ao qual ele mesmo fazia jus - isto é, de acordo com a lei uma vez que a pena de morte é lei, a nós somente cabe aplicá-la, servi-la. E tampouco creio que possa haver um caso mais prontinho do que este para a pena capital, pois a pena capital é um fato, pois a pena capital é lei: crimes frios, bestiais; personagem abjeto... a cidade toda está indignada, revoltada: dá pra sentir no ar uma sensação de linchamento... Mas se estou bem lembrado - sem ironia, com pesar, quase com dor - o senhor preferiria, o linchamento...

- Não, não preferiria. O que disse então, lembro-me bem, é que um bando de fanáticos ou exaltados que acredita fazer justiça contrariando, na verdade, o direito, acaba justamente por reafirmá-lo: no sentido de aquela ação impor àqueles que levam a cabo o ressarcimento do direito, a afirmação que aquilo não pode ser, que é proibido... $\mathrm{O}$ senhor não pode esquecer, afinal, que os instintos em ebulição num linchamento, furor, a loucura, possuem no fim das contas menos atrocidade do que o ritual macabro proporcionado por um Tribunal de Justiça que profere um sentença de morte: uma sentença que justamente em nome da justiça, do direito, da razão, do rei pela graça de Deus e pela vontade da nação, entrega um homem que, alistados para garantir o bem dos cidadãos, aquele supremo que é a vida, a certa altura ouviram a chamada, e a ela responderam de boa vontade, para um assassinato não só impune como também premiado...Uma vocação para ao assassinato que se realiza com gratidão e gratificação por parte do Estado (SCIASCIA, 1990, p. 14).

Como se vê, a tentativa de constrangimento do pequeno juiz, por parte do procurador geral - que arrisca

persuadi-lo a mudar de opinião ou a deixar o tribunal -, revela dois aspectos preliminares: primeiro, a sujeição ao partido, que cobrava obediência de tudo e de todos; segundo, quando o procurador argumenta que a pena de morte é lei, a nós somente cabe aplicá-la, servi-la, evidencia-se o paradigma jurídico técnico-positivista que tornou possível a instrumentalização do direito por meio da maximização e a radicalização dos poderes políticos.

A articulação desses dois aspectos conduziu, para além de experiências nefastas como a restauração da pena de morte, incontáveis injustiças sob o manto do direito. Uma prova disso é que, para o procurador geral, não havia um caso mais pronto do que aquele: três homicídios supostamente premeditados equivalia à pena de morte. Além disso, a "ferocidade" do crime havia chocado a comunidade siciliana que, indignada com o acontecido, exigia 
que o culpado fosse punido severamente. Eis a máquina judiciária e o clamor social...

Ademais, o regime fascista não admitia posições neutras. Qualquer pessoa que assumisse uma opinião moderada era considerada inimiga e, portanto, deveria ser vigiada. Essa exigência de obediência proveniente de regimes totalitários é explicada por Todorov, para quem tais sistemas de governo são maniqueístas e dividem o mundo em duas partes mutuamente excludentes: de um lado, os bons; de outro, os maus. Assim, considerando que o objetivo do regime é a eliminação dos maus, o Estado impõe o terror generalizado como legítimo para defender os ideais nacionalistas (TODOROV, 2002, p. 39-42).

Ocorre que essa cisão maniqueísta da sociedade reduz a diferença à oposição e intenta eliminar o mais rápido possível, aqueles que a personificam, negando radicalmente qualquer noção de alteridade. A pluralidade vem, desse modo, substituída pelo senso de coletividade universal. E isso é tão forte, tão contundente, que os princípios da guerra são incorporados na vida civil, de maneira que o inimigo - representado pelo diferente merece nada menos que a morte. Trata-se, com efeito, de universalismo hostil, que prega o estabelecimento da paz, porém promove precisamente o contrário daquilo que professa (TODOROV, 2002, p. 39-42).

A restauração da pena de morte na Itália configura um dos instrumentos deliberadamente impostos pelo regime fascista, que objetivava controlar a sociedade através da opressão e do medo, a fim de manter o monopólio do poder. E o pequeno juiz sabia disso. Ele tinha ciência de que a pena capital "representou mais um mecanismo de controle dos cidadãos por parte do Estado, mais um discurso que convencia sobre uma aparente tranquilidade e segurança generosamente proporcionado pelo Estado fascista" (SCIASCIA, 1990, p. 23).

Contudo, para o pequeno juiz, em nenhum momento é possível justificar a morte como pena. Mesmo que se esteja diante de um crime hediondo, praticado com tamanha violência, não há argumentos que sustentem a possibilidade de o Estado institucionalizar a barbárie em nome da justiça e do bem comum. Ele era filho de uma geração iluminista, que havia presenciado a abolição da pena de morte, considerada um avanço para a sociedade, e conquista a liberdade (COUTINHO, 2015, p. 223). Portanto, não seria possível concordar com os termos da sua restauração no ordenamento jurídico italiano. A preservação da vida é uma questão de princípio; afinal, ela é o bem supremo de um homem ${ }^{18}$.

Tal posicionamento não era, entretanto, compartilhado pelo procurador geral que, irritado com os comentários do juiz acerca do processo, resolve desistir de convencê-lo. Mesmo insatisfeito com o resultado de

\footnotetext{
${ }^{18}$ Como se vê, embora não haja qualquer referência expressa, a novela de Sciascia também dialoga com a conhecida obra de Victor Hugo (2010), O último dia de um condenado, escrita em 1829, na qual o narrador descreve a agonia que marca as últimas semanas de vida de um prisioneiro francês, sentenciado à morte, não se sabe pela prática de qual crime. Nesse livro, em que não se cita o caso específico e não se nomeia o protagonista, o autor deixa deliberadamente de mencionar as motivações que ensejaram a condenação. Isso torna a obra absolutamente atual, na medida em que provoca a reflexão acerca da finalidade do direito, das funções da pena e da falibilidade do sistema judiciário, defendendo a necessidade de preservação da vida. A narrativa evidencia que o homem condenado à morte é destruído pela espera da execução da pena. Há um duplo sofrimento: o primeiro, a espera, pode ser ainda pior do que o segundo, a própria morte. Trata-se, em suma, de um libelo contra a institucionalização da tortura (prévia à _vol.09, no. 04, Rio de Janeiro, 2016. pp. 2124-2149 2133
} 
suas investidas, ele confiava que a opinião do pequeno juizera bastante inútil: "acima de qualquer opinião estava a lei" (SCIASCIA, 1990, p. 16).

O procurador geral acreditava, de fato, que a restauração da pena de morte consistia num eficiente mecanismo capaz de diminuir os índices de criminalidade. E esse era um dos principais objetivos estabelecidos pelo Partido Fascista, isto é, a implementação de políticas de segurança pública capazes de promover a tranquilidade dos cidadãos:

- Como o senhor sabe, é de domínio público que aqui, desde que o fascismo chegou ao poder podemos dormir de portas abertas...

- Eu continuo fechando a minha - disse o juiz.

- Eu também: mas não podemos negar que as condições de segurança pública, de uns quinze anos para cá mudaram bastante. Até aqui na Sicília, apesar de tudo. Agora, quaisquer que sejam as nossas opiniões acerca da pena de morte, temos que admitir que a restauração serve para inculcar na cabeça das pessoas a ideia de um Estado que se preocupa ao máximo pela segurança dos cidadãos; a ideia de que realmente as pessoas durmam de portas abertas (SCIASCIA, 1990, p. 17).

Como se vê, a alegoria das portas abertas apresenta-se como metáfora capaz de exprimir as ideias de suprema ordem e de segurança, levada a efeito pelo controle da criminalidade que o regime fascista aparentemente alcançara. Eis, um discurso demagógico que, conforme demonstrou a História, encontrou terreno fértil no imaginário da sociedade italiana. Em verdade, as portas abertas não simbolizam a eficiência de alguma política pública, mas sim a deliberada e ilimitada intervenção por parte do Estado, que invade a esfera da vida privada (IZZO, 2010).

De outro lado, não se pode esquecer, as portas que realmente se mantinham trancadas eram as portas dos jornais. Esses sim fechavam muito bem as suas portas, limitando a divulgação de notícias que sempre eram controladas pelo filtro do regime fascista, como narra Sciascia (1990, p. 25). Trata-se do conhecido silêncio eloquente que endossava ainda mais a ideia de controle imposta à sociedade na época. Tanto que crimes graves, tais como o do tríplice homicídio, raramente eram noticiados pelos meios de comunicação.

Segundo Hermann Heller, a lógica da ditadura exigia a supressão, de todas as formas, da livre manifestação de pensamento. A opressão espiritual da ditadura resultou extraordinariamente sensível para os italianos, povo inteligente e culto. Durante o ventennio fascista, os italianos tinham que observar sempre todos os lados cautelosamente, antes de pronunciar uma palavra sobre questões políticas, por mais insignificante que ela parecesse. $O$ regime fascista editara uma lei de segurança que exigia a autorização do governo para a publicação de qualquer matéria, sendo proibidas todas aquelas que fossem contrárias à ordem pública da nação ou ofendessem o prestígio das autoridades do regime, a moral e os bons costumes ${ }^{19}$.

execução) e da violência que fundam a lei da civilização (SZAC, 2010; JEAN, 1992).

${ }^{19}$ Heller (2006, p. 75-76) destaca que o partido fascista se ocupou de suprimir a raiz da liberdade de imprensa, garantida no artigo 28, da Constituição, e nos artigos 1 e 35, do Edito de 26 de março de 1848. O partido monopolizou a imprensa, utilizando-a como um meio importante de formação de opinião pública. A violência contra a imprensa foi cometida não somente por disposição de vol.09, nº. 04, Rio de Janeiro, 2016. pp. 2124-2149 2134 
Encerrada a conversa com o procurador geral, ao deixar o Palácio da Justiça, o pequeno juiz recorda-se da Inquisição. Lembrou que, por anos, pessoas foram queimadas em nome da justiça. Tudo porque a vontade havia sido transformada em lei. No entanto, tinha certeza de que não estava errado, nem sozinho. Quando chegou em casa, dirigiu-se imediatamente à biblioteca, onde consultou diversas obras filosóficas e literárias. Não sabia precisar ou definir aquilo que defendia, mas tinha certeza de que acreditava na coisa. Pretendia fundamentar mais solidamente suas aspirações de liberdade e proteção à vida. Para ele, não era admissível permitir, no ano de 1937, "que a humanidade, que o direito, que a lei - e afinal o Estado que a filosofia idealista e a doutrina fascista chamavam de ético - respondesse ao assassinato com assassinato" (SCIASCIA, 1990, p. 20). Isso não poderia ser um avanço; ao contrário, representava um retrocesso à barbárie.

No início da audiência, o pequeno juiz observava o acusado diante de si, refletindo, de novo, sobre os motivos que levaram à restauração da pena de morte. A cada sessão, ele sentia-se trespassado por uma onda de intermitência, inquietação, contradição. Percebia estar incumbido de um caso que, mesmo o mais justo dos homens, iluminados por graça ou razão, teria de levar em conta a parte mais obscura de si.

Em seu interrogatório, o acusado descreveu minuciosamente os fatos, pois se recordava, com detalhes, tanto da execução como dos atos que precederam os crimes. Tudo conforme tinha imaginado. Tudo segundo havia premeditado. Isso o conduzia, facilmente, a uma sentença que o condenaria à pena capital. Seu destino parecia ser inexorável. As testemunhas, por sua vez, mostravam-se cautelosas, pelo medo de comprometerem-se politicamente ou, então, pela repulsa instintiva de se afastar de um homem que se revelara uma "fera" ao premeditar friamente três homicídios (SCIASCIA, 1990, p. 39).

A defesa permanecia silente. Quase ausente. Na verdade, os advogados se recusaram a defender o acusado. Todos eram solidários ao colega que fora uma das vítimas do crime. Seu defensor precisou ser designado pela procuradoria geral. Ao (não) exercer sua função, a defesa deixou de solicitar perícia, perdendo a oportunidade de comprovar a potencial loucura do acusado. Em suma: nada fora feito por respeito à própria classe. Uma omissão elementar, num caso como aquele, em que operavam todas as engrenagens da máquina judiciária (SCIASCIA, 1990, p. 44).

As reflexões do pequeno juiz o direcionam, lentamente, para o sentimento de certa empatia pelo acusado: "Desse jeito, meditando sobre o andamento técnico daquele processo e relacioná-lo com [...] a memória de coisas lidas ou pensadas a partir das leituras, o juiz ia aproximando-se pouco a pouco do acusado, da sua

órgãos subordinados, mas também pelo próprio Mussolini. Foi através da elaboração de normas jurídicas que o primeiro ministro controlou a liberdade de imprensa. A opressão foi tanta que os periódicos não poderiam ser publicados sem autorização prévia do partido. Além disto, para o próprio exercício da profissão era necessária a inclusão do nome em uma lista de periodistas profissionais. A inclusão ou exclusão do profissional nessa lista dependia de sua conduta ter posto em jogo ou não os interesses da nação. Evidentemente que a tendência era de rechaçar aqueles que não compactuavam de algum modo com a ideologia fascista. $\mathrm{O}$ diretor responsável pelo controle de tais periódicos poderia ser destituído de seu cargo a qualquer momento pelo prefeito, a quem correspondia também o direito de revogar a todo momento a autorização de publicação de algum periódico. 
retorcida e feroz humanidade, da sua loucura: em resumo, como era o seu dever, tornava-o para si penosamente visível" (SCIASCIA, 1990, p. 45).

Aqui, mais uma vez, o narrador reitera o papel desempenhado pela literatura. Enquanto ouve o acusado, o pequeno juizrecorda-se da leitura das obras literárias e filosóficas que contribuíram para sua formação, ao longo da vida. São elas que, curiosamente, permitem sua "aproximação" do acusado ${ }^{20}$.

Entre os seis jurados que haviam sido sorteados (um era suplente), praticamente nenhum sinal de ternura - em relação ao acusado, certamente nenhuma -, nem mesmo em relação à vida, à ordem ou à desordem da vida. De todo modo, o pequeno juiz estabeleceu uma relação de simpatia com os jurados, especialmente com o agricultor, com quem logrou um entendimento silencioso, pois em dada ocasião o tinha ouvido falar sobre alguns temas literários. E isso era o suficiente para compreender que, certamente, partilhavam da mesma tese: independentemente do motivo, nunca será legitimo condenar alguém à morte.

É importante assinalar o fato de ser a literatura - no sentido de representação e significação do mundo compartilhada e compartilhável - o que aproxima o juiz do agricultor, ambos dados à evocação da memória e à reflexão, ambos capazes de fazer uma leitura crítica da realidade e de imaginar um mundo melhor ${ }^{21}$.

O pequeno juiz seguia resistente. Para ele, "não se tratava apenas de um problema de justiça, de administrá-la conforme a lei ou de afirmá-la contra a lei; tratava-se também de liberdade interior, de qualquer forma devida a quem é chamado a julgar" (SCIASCIA, 1990, p. 63). Tal resistência advinha da consciência que tinha acerca da responsabilidade política exigida de todo aquele que tem o dever de julgar. Uma coisa é discutir a questão da pena de morte em uma mesa de bar; outra, bem diferente, é assinar a sentença que impõe a pena capital, como adverte Salvatore Satta (1968) no epílogo da obra:

Na realidade quem mata não é o legislador, mas o juiz; não é a medida legislativa, mas a medida jurisdicional. O processo, ao apresentar-se diante da lei e do poder com a sua autonomia própria total, uma autonomia na qual e pela qual o poder, como ato arbitrário de domínio, se dissolve, e ao impor-se seja ao dominado seja a quem formulou a ordem, encontra, fora de qualquer conteúdo revolucionário, o seu "momento eterno" (SCIASCIA, 1990, p. 3).

\footnotetext{
${ }^{20}$ A respeito das possíveis influências da literatura sobre os juízes, Nussbaum $(1996,2010)$ defende a polêmica posição de que, ao oferecerem conhecimento sobre conteúdos universais, problemas éticos e valores morais, as narrativas literárias promovem um sentimento empático e de identificação entre o leitor e as personagens. Essa aproximação instiga o leitor a reconhecer-se e a participar da vida da personagem, através da imaginação. Assim, as emoções possibilitariam a geração de um sentimento de solidariedade e de percepção de humanidade comum. E isso seria um importante mecanismo na formação crítica que, embora não ofereça respostas para os problemas sociais, pode indicar alguns caminhos na direção de uma ideia de justiça.

${ }^{21}$ Merece destaque a riqueza de referências históricas, filosóficas e literárias que figuram na novela, vinculadas às leituras ou às reflexões do protagonista. No inventário dos pensadores e obras evocados, encontram-se: Cesare Lombroso (p. 15); A disputa em torno do sargento Grischa, de Arnold Zweig (p. 16); Vitaliano Bracanti (p. 20); Niccolò Tommasèo (p. 25); Henri-Marie Beyle, mais conhecido como Stendhal (p. 32); Cristoforo Roncalli, um pintor maneirista conhecido como Il Pomarancio; (p. 32); Hamlet, de Shakespeare (p.42); Vittorio Alfieri (p. 42); François, Duque de La Rochefoucauld (p. 44); Marcel Proust (p. 47); Dafni e Cloé, de Paul-Louis Courier (p. 48); Francesco Guicciardini (p.50); Advertências cristãs, de Argisto Giuffredi (p. 50); Cesare Beccaria (p. 50); Giuseppe Pitrè (p. 53), Diodoro Sículo (p.53); Dom Quixote, de Cervantes (p. 60); Alberto Savinio (p. $60)$.
} 
$\mathrm{Na}$ mesma linha, Robert Cover entende que a interpretação das normas jurídicas configura uma imposição de violência. Quando um juiz articula algum argumento sobre a aplicação de determinada regra, os sujeitos envolvidos no processo sofrem consequências que podem ser a perda de liberdade ou da vida. No fim das contas, aplicar a lei também é uma forma de violência organizada e institucionalizada ${ }^{22}$.

No dia do julgamento, após longa discussão, o conselho de sentença retornou à sessão com uma sentença que não a de morte. Considerando que a defesa não requereu o exame de insanidade mental, o que lhe permitiria alegar a inimputabilidade do acusado e atenuar a sanção a ser imposta, o pequeno juiz recorreu ao instituto da continuidade delitiva (SCIASCIA, 1990, p. 71). Trata-se, portanto, de uma solução encontrada dentro do próprio ordenamento jurídico, uma espécie de uso alternativo do direito ${ }^{23}$. Seu voto fora acompanhado pelos demais jurados, a começar pelo agricultor. No entanto, como se pode imaginar, tal decisão deixou descontente muitos daqueles que acompanhavam o caso, principalmente os membros do partido fascista.

Passados alguns dias após o julgamento, o pequeno juize o procurador geral encontraram-se novamente. $\mathrm{Na}$ ocasião, conversaram sobre o processo. Para o procurador geral, a sentença que poupou a vida do acusado tinha sido em vão e, ainda, prejudicial à carreira do pequeno juiz. A decisão - levada a cabo pelo pequeno juiz e acompanhada pelos jurados - despertou no senso comum certo ressentimento. A crença compartilhada, embora imposta, era de que a justiça só é feita quando há efetivamente uma punição severa, baseado na ideia de retribuição da pena na mesma medida da agressão. Além disso, a sentença teria apenas protelado o sofrimento do acusado que, de qualquer modo, seria condenado à pena morte. Afinal, um recurso já havia sido encaminhado para a Corte de Apelação, argumentando que, diante da pena imposta e da gravidade do crime, a lei havia sido violada. Em suma, naquele caso, a justiça não teria sido feita:

\footnotetext{
${ }^{22}$ Segundo Cover (2002, p. 114-116), a palavra "interpretação" pode ser enganosa. Enquanto sugere que opera com a construção social de uma realidade interpessoal através da linguagem, seus resultados implicam circunstâncias distintas, tal como a dor e a morte, as quais destroem o mundo que a interpretação evoca. $\mathrm{O}$ fato de a habilidade de construir realidades interpessoais através da interpretação seja destruída pela morte é óbvio. O que é certo acerca da morte, também é certo acerca da dor, porque a dor destrói, entre outras coisas, a própria linguagem.

${ }^{23}$ A respeito do uso alternativo do direito na Itália, Ferrajoli (2004, p. 224-226) leciona: "el desarrollo de una jurisprudencia que se llamó alternativa, y que simplemente pretendía hacer efectiva la (por tanto tiempo olvidada) primacía de la Constitución sobre la legalidad viciada que había dado fundamento a las orientaciones jurisprudenciales dominantes en materia de derecho del trabajo, de delitos de opinión y sindicales, de libertad personal, de garantía de los intereses difusos, de tutela de la seguridad y de la salud en los lugares de trabajo y de protección del ambiente [... ] las fórmulas jurisprudencia alternativa y uso alternativo del derecho - esta última surgió como título de un Congreso entre juristas de izquierda, que tuvo lugar en Catania entre el 15 y el 17 de mayo de 1972 y, posteriormente, fue retomada en el título de los dos volúmenes editados por P. Barcellona - L'uso alternativo del diritto, RomaBari, Laterza, 1973 -, más que un movimiento verdadero, expresan una actitud genérica de impugnación de la cultura jurídica tradicional. En su uso original, la primera de las fórmulas, sólo significaba jurisprudencia alternativa a las orientaciones jurisprudenciales dominantes que ignoraban a la Constitución y de las que buscaba impugnaba su presunto monopolio ideológico de la legitimidad jurídica y, al hacerlo, verter sobre de ellas una acusación de ilegitimidad. De hecho, más allá de su carácter polémico, se trató de una jurisprudencia que hoy llamaríamos garantista y que se caracterizaba por reconocer la supremacía de la Constitución en materia de interpretación y aplicación de la ley. El éxito de la segunda fórmula de debe a la distorsión de su significado, siendo que es difícil encontrar en los volúmenes que he citado, junto con las múltiples proclamaciones ideológicas y las vol.09, no. 04, Rio de Janeiro, 2016. pp. 2124-2149 2137
} 
- Como o senhor sabe, eu estou perfeitamente de acordo com ele (os termos do recurso): mas eu sei, como todos sabem, e talvez ele mesmo saiba, que o elemento leigo, como ele chama o júri, rendeu-se à opinião.

- Minha: é isto que o senhor quer dizer?... Mas (o júri) não se rendeu coisa nenhuma: já tinha o que o senhor chama de opinião e eu chamo de princípio. E é um princípio de tal força, o contrário à pena de morte, que da para sentir que se está certo mesmo que se fique sozinho a defendê-lo... Não tenho motivos de queixa, portanto, se alguém quer acreditar que eu manipulei a tal ponto as razões para não se aplicar a pena de morte até conseguir convencer um júri renitente... Só que, em hora e defesa do júri, posso dizer que ele não era nem um pouco renitente.

- Folgo em saber - disse o procurador.

- E por quê?

- Dentro de alguns meses vou-me embora; deixo o escritório, esta profissão. A aposentadoria. Terrível por que não admiti-lo, para quem teve poder como eu tive. Mas estou me acostumando: estou começando a pensar coisas nas quais nunca pensei antes. Por exemplo: que sempre fui um morto que sepultava outros mortos. E, aliás: todos nós somos, neste nosso ofício de acusar e de julgar. E mais: me pergunto se, na função de mortos que sepultam mortos, temos realmente o direito de sepultar mortos por pena capital. Mas veja bem: é uma pergunta; e a resposta que encontra ainda é sim, que temos este direito, se a própria lei nos impõe isto... Mas quando há pouco, eu disse estar perfeitamente de acordo com os termos do recurso, assim como da outra vez eu disse que estava perfeitamente de acordo com Rocco, pois bem: o perfeitamente não corresponde ao que realmente sinto. Há algo, no afirmar a lei até aquele ponto que me irrita, me inquieta... No limiar da velhice, da aposentadoria, talvez até da própria... gostaria de compreender... Foi por isto que, esta manhã decidi falar com o senhor: para entender o que está acontecendo com o senhor, o que passa pela sua cabeça, o que lhe causa receio... E não me refiro à carreira, pois o senhor é o primeiro a saber que a jogou fora, aliás, sabia disto desde o começo; quero dizer em relação à consciência... à vida... (SCIASCIA, 1990, p. 82-83).

Apesar de vinculado ao partido fascista e conivente com a pena de morte, ao chegar ao final da carreira, à véspera da aposentadoria, o procurador geral revela que sua cumplicidade com a pena de morte não resultava de uma ideologia, mas era uma questão corporativista, comum nos operadores do direito de viés mais tecnicista, formalista, positivista.

Na verdade, o questionamento que o procurador geral começa a se fazer a respeito da legitimidade da lei - ou, de um modo geral, da realização da justiça - o conduzem a interessante reflexão:

- Eu estaria mentindo se dissesse que estou tranquilo [disse o pequeno juiz].
- É o que eu pensava.
- Entenda bem: estou convencido de que cumpri o meu dever de homem e de juiz; estou
convencido de que trabalhei, tecnicamente, com os argumentos jurídicos, como melhor não
teria sido possível... O argumento príncipe teria sido o da insanidade; uma vez que não
dispunha dele, procurei substituí-lo considerando três homicídios na continuidade de um
único plano criminoso... Agora fico pensando com horror no que poderá acontecer... medo:
é isso que sinto (SCIASCIA, 1990, p. 84).

Mas o procurador geral já sabia exatamente o que aconteceria. Ele podia antever. O Supremo Tribunal irá anular a sentença, que será reformada pelo Tribunal de Recursos de Agrigento, onde o juiz que será responsável por julgar o processo tem certa afeição pela pena de morte. Haverá um advogado socialista que assumirá a defesa

numerosas indicaciones progresistas en las diferentes disciplinas jurídicas, justificaciones para las acusaciones de derecho libre o de infidelidad al derecho de las que es objeto". 
do acusado, justamente para que o Partido Fascista possa demonstrar que existe processo com contraditório. Será uma defesa esquálida, para ser esmagada. A condenação à pena capital, já estaria pronta.

Isso permite concluir que, na ótica do procurador geral, o pequeno juiz simplesmente colocara em xeque sua brilhante carreira. Tudo em vão, como adverte: "haverá sentença de morte, o acusado será fuzilado... E então? Para que serviu a sentença a não ser para prolongar-lhe a agonia?” (SCIASCIA, 1990, p. 84).

Para o pequeno juiz, ao contrário, tratava-se de uma questão de esperança. Ele afirma que a condenação à pena de reclusão oferecia um fio de esperança ao qual o acusado se agarraria durante o tempo exigidos para a apreciação dos recursos e para o julgamento final. Uma esperança tênue que seria substituída pela agonia no dia em que fosse acordado para ser fuzilado. Sem dúvida, a sentença prolatada protelou o sofrimento do acusado. No entanto, a vida vale mais do que a morte, e vivê-la um dia, meses ou anos parece ser uma dádiva. É claro que o procurador geral não compreende isso:

- Mas o senhor não acha que está procurando álibis para si mesmo, para a vaidade, podemos
bem dizer isto, do seu lugar de protesto dentro de um contexto que só lhe permite carregar
de sofrimento ainda maior o ser humano sobre o qual o senhor concentrou a defesa de um
princípio, e que, afinal, na defesa deste princípio não foi levado devidamente em conta o
sofrimento daquele homem?
- Concordo que a defesa do princípio, para mim, contou mais do que a vida daquele
homem. Mas é um problema, não um álibi. Eu salvei a minha alma, os jurados a deles: o que
pode até parecer muito cômodo. Mas imagine o que aconteceria se, em cadeia, todo juiz
cuidasse de salvar a própria alma... (SCIASCIA, 1990, p. 86).

Ora, apenas porque tinha convicção de que fez a coisa certa, sem qualquer consequencialismo, e de que era responsável politicamente por tal decisão é que o pequeno juiz salvou a sua alma. Eis aquilo que a teoria jurídica contemporânea denomina decidir por princípio, como se verá na sequência.

\section{A LIÇÃO DE SCIASCIA: O PAPEL DOS PRINCÍPIOS NA CONSTRUÇÃO DAS DECISÕES}

Desde o clássico debate entre Hart e Dworkin, ainda nas décadas de 70 e 80, os princípios jurídicos ocupam um lugar de destaque no campo da teoria do direito contemporâneo (RODRÍGUEZ, 2000). A conhecida posição de Dworkin busca superar a concepção de direito apenas como um modelo de regras, nos termos propostos pela filosofia jurídica analítica. Para ele, o direito é uma prática interpretativa que envolve um conjunto de padrões normativos que também abarca os princípios:

A diferença entre princípios jurídicos e regras jurídicas é de natureza lógica. Os dois conjuntos de padrões apontam para decisões particulares acerca da obrigação jurídica em circunstâncias específicas, mas distinguem-se quanto à natureza da orientação que oferecem. As regras são aplicáveis à maneira do tudo-ou-nada. Dados os fatos que uma regra estipula, então ou a regra é válida, e neste caso a resposta que ela oferece deve ser aceita, ou não é válida, e neste caso em nada contribui para a decisão (DWORKIN, 2002, p. 39). 
Mas isso não é tudo. Dworkin adverte, ainda, para uma segunda distinção - essa sim fundamental ao argumento do presente ensaio - entre princípio (principle), entendido como "padrão que deve ser observado, não porque vá promover ou assegurar uma situação econômica, política ou social considerada desejável, mas porque é uma exigência de justiça ou equidade ou alguma outra dimensão da moralidade” (2002, p. 36), e política (policy), entendida como "padrão que estabelece um objetivo a ser alcançado, geralmente uma melhoria em alguma característica econômica, política ou social da comunidade” (2002, p. 36).

Portanto, os princípios são padrões que guiam um argumento em determinada direção. Eles estão inseridos no mundo prático e podem ser encontrados na doutrina, na jurisprudência e nos precedentes. Os princípios subjazem às regras e aos casos à medida que sua aplicação exige coerência com a tradição jurídica de determinada comunidade política. Assim, eles apontam elementos interpretativos e parâmetros decisórios, impedindo que os juízes decidam segundo sua orientação política, moral ou religiosa e tampouco de acordo com sua consciência ou para atender aos anseios da sociedade ${ }^{24}$.

Como assinala Coutinho, há algo para além da lei e que a funda. É por isso que o dilema filosóficojurídico que se coloca nesta novela de Sciascia pode ser facilmente compreendido à luz da teoria jurídica de Dworkin. O pequeno juiz - que é o alterego e porta-voz de Sciascia - decide por princípio: a vida, para ele, é aquele bem supremo sobre o qual não se negocia, nem mesmo quando se ocupa o lugar onde o poder se materializa, ou seja, a decisão judicial(COUTINHO, 2015, p. 226-228).

A mesma concepção principiológica, no Brasil, pode ser encontrada na Crítica Hermenêutica do Direito, a partir da qual Lenio Streck $(2016,2014)$ propõe sua teoria da decisão judicial: princípios não são teleológicos, mas deontológicos, na medida em que eles revelam um padrão decisório que se constrói historicamente e que gera um dever de obediência no interior de dada comunidade política.

Tudo indica que a solução para o caso penal posto em Portas abertas era relativamente simples. A um crime hediondo - na verdade, um triplo homicídio - deveria ser aplicada a regra prevista na legislação fascista vigente à época que resultaria na punição com a pena capital. Todavia, esse não foi o caminho tomado pelo pequeno juiz. E por que não? Porque ele construiu sua decisão - e foi seguido pela maioria dos juízes leigos - a partir de um princípio: nada justifica a pena de morte. Eis, aqui, a grande lição de Sciascia.

A sentença que poupou a vida do acusado fora surpreendente, principalmente àqueles que aguardavam a automática execução sumária. Ocorre que, para o pequeno juiz, a condenação à morte era impossível desde o princípio. O Estado não está legitimado a assassinar ninguém. Em hipótese alguma: nem pelas conhecidas "razões de Estado”, nem sob o argumento retórico de que “a punição exemplar evita a prática de novos crimes”, nem que a

\footnotetext{
${ }^{24}$ Segundo a conhecida teoria de Dworkin, (2014), o direito é um conceito interpretativo. Encontrar um princípio que assegure a proteção de um direito consiste necessariamente em interpretar da melhor forma possível as práticas jurídicas de uma comunidade. vol.09, nº. 04, Rio de Janeiro, 2016. pp. 2124-2149 2140
} 
legislação fascista assim o estabeleça. Essa última hipótese revela, no fundo, uma lei sem um princípio que lhe dê sustentação. Uma lei violadora da dignidade e do direito individual mais primitivo: o direito à vida.

Como já dito, o pequeno juiz evita afrontar diretamente a lei. Ele decide apesar da lei, e não contra a lei. $\mathrm{Na}$ verdade, para dar aplicação ao princípio que defende, o pequeno juiz utiliza-se das normas do próprio ordenamento jurídico, aliando a passionalidade à continuidade delitiva, a fim de atenuar a sanção a ser imposta ao acusado, livrando-o, assim, da pena capital. Trata-se, com efeito, de um uso alternativo do direito, empregado ao longo da história - inclusive no Brasil - contra o direito ilegítimo produzido pelos sistemas autoritários antes da consolidação do paradigma do Estado Constitucional.

Observa-se, com isso, que o pequeno juiz representa a melhor tradição iluminista - e garantista - do século XVIII, que impulsionou o constitucionalismo liberal ${ }^{25}$. Sua posição, entretanto, era não apenas incomum entre os juízes da época, mas também indesejada. Isso porque, conforme destaca Stolzi (2014), a ideologia fascista se expressou, no campo do direito, através de um grupo de juristas do próprio regime, que formou uma cultura jurídica fascista, reconhecida por sua específica forma de pensar o Direito. Instituiu-se uma ideologia positivistalegalista, de matriz técnica, compatível com um conteúdo radicalmente novo, proposto pela renovação que o fascismo se empenhou em estabelecer na comunidade italiana.

Com a ascensão do fascismo, houve a restauração da pena capital no sistema jurídico italiano, promovendo-se a quebra da tradição iluminista e o retrocesso no campo dos direitos e garantias de liberdade.

Registre-se, por oportuno, que a história italiana da luta contra a pena de morte remonta ao ano de 1786, quando, em Florença, o arquiduque austríaco Leopoldo di Lorena (1747-1792), ao reformar o Código Penal, eliminou as penas de morte e de tortura. Isso tornou o Granducato di Toscana o primeiro reino europeu a abolir, formalmente, a pena de morte. Tal impulso ocorreu devido à influência iluminista exercida por Cesare Beccaria (1965), que havia publicado a clássica obra Dei delitti e delle pene, em 1764. Seguindo essa mesma tradição, a pena de morte é também abolida, em 1848, pela República Romana, proclamada por Mazini e Garibaldi.

Quase um século depois da abolição inaugurada pelo Granducato di Toscana, com a unificação italiana,

É esse o ponto de ajuste de uma decisão judicial em um caso concreto: o fato de que a melhor interpretação sobre o direito mantém a continuidade da história e da tradição institucional.

${ }^{25}$ Muito embora os iluministas objetivassem levar a efeito, de um modo geral, a limitação do poder político e a inclusão das classes populares na participação política, tal objetivo teve sua eficácia restringida pelos influxos contrarrevolucionários de caráter liberal, autoritário e elitista. Se, por um lado, as revoluções lograram êxito com a limitação do poder político através da lei, lançando as bases para as escolas técnico-positivistas que se consolidaram nos anos subsequentes; por outro lado, os movimentos conservadores contrarreforma, liderados pela burguesia, adquiram o controle do poder político, promovendo a marginalização e a desapropriação do poder constituinte popular. Em consequência disto, a experiência liberal oitocentista criou um abismo entre os objetivos declarados e a (falta de) sua realização. Essa circunstância criou campo fértil para a ascensão dos regimes totalitários no início do século XX. Assim, os ideais libertários do Iluminismo que ecoavam pela Europa desde o século XVIII, foram abruptamente interrompidos com o surgimento dos movimentos totalitários, que se aproveitaram do ranço do liberalismo autoritário oitocentista, da cultura jurídica positivista-legalista e, ainda, da promessa de revolução baseada na vontade popular (PISARELLO, 2014, p. 82-83). 
em 1865, instalou-se um acirrado debate acerca das diferenças existentes entre os sistemas jurídicos vigentes nos diversos reinos da península. O maior obstáculo que se colocava era relativo ao fato de que a Toscana já havia abolido a pena de morte, enquanto os outros reinos - que ainda estavam sendo anexados - não tinham adotado a mesma postura. Ao final do debate sobre a função e possível legitimidade da pena, prevaleceu o argumento de que a Itália deveria ser exemplo para os demais Estados europeus, assumindo a vanguarda da abolição da pena capital (MEREU, 2000, p.39 e 55).

Como se sabe, os iluministas italianos foram determinantes no enfrentamento dessa questão. Nesse sentido, juristas como Pietro Ellero, juntamente com Francesco Carrara e Carlo Francesco - todos integrantes da Scuola Positiva Penale -, elaboraram um periódico chamado Giornale per l'abolizione della pena di morte. Tal projeto contava com a colaboração de juristas italianos e estrangeiros que discutiam, a partir dos ideais iluministas de Beccaria, a crueldade da pena de morte e a necessidade de eliminá-la (ACERBI, 2003, p. 183). Os debates promovidos pela Scuola Positiva Penale foram fundamentais para a propagação dos ideais libertários. Tanto que a difusão das discussões acabou por influenciar diretamente a elaboração do Codice Zanardelli, em 1889, que aboliu de uma vez por todas a pena de morte do sistema jurídico italiano (SBRICCOLI, 2009).

Isso revela que a restauração da pena de morte, em 1926, mediante alteração legislativa proposta por Benito Mussolini ${ }^{26}$ - à época primeiro-ministro, líder do governo fascista -, e, em 1931, ampliada pelo Codice Rocco, significou o retrocesso de uma conquista civilizatória que já contabilizava 140 anos (SIMONE, 2012, p. $189)^{27}$.

É nesse contexto - marcado pelas reminiscências de uma tradição jurídica iluminista interrompida abruptamente diante da instauração do governo fascista - que se encontra o protagonista de Portas abertas. $\mathrm{O}$ pequeno juiz - filho de uma geração de iluministas, conhecedor da obra de Beccaria - tinha plena consciência de que a abolição da pena de morte era resultado da consolidação de conquistas alcançadas ao longo dos séculos.

Sua defesa do princípio, resistência ao fascismo e oposição ao utilitarismo refletem, de acordo com Bobbio (2004, p. 180), aquilo que Benedetto Croce escreveu, em 1928, na Storia d'Italia: "a abolição da pena de morte tornara-se uma questão de costume, de tal maneira que a simples ideia de sua restauração era absolutamente incompatível com o sentimento nacional”28.

\footnotetext{
${ }^{26} \mathrm{~A}$ reforma da legislação penal levada a cabo por Mussolini foi uma resposta a atentado praticado contra ele. Seu propósito inicial era reprimir ataques contra o primeiro-ministro e contra o próprio regime fascista, imputando-se a pena de morte aos crimes de atentado contra os mais altos cargos do Estado, isto é, contra a família real e o chefe de governo. Entretanto, com o tempo, a medida estendeu-se para qualquer outro crime que viesse a por em risco a segurança do Estado, sendo definitivamente incorporada no Código de Rocco, em 1930 (LACCHÈ, 2015).

${ }^{27}$ Superado o vintênio fascista, a pena capital vem abolida apenas com o advento da Constituição italiana de 1947, salvo nos casos previstos nas leis militares de guerra, tal qual a previsão brasileira. Essa exceção, constante no artigo 27, 3, foi revogada, em 2007, por meio da emenda constitucional.

${ }^{28} \mathrm{Na}$ verdade, a citação atribuída a Benedetto Croce é originária da conferência intitulada Contro la pena di morte, proferida por Norberto Bobbio, durante a VI Assembleia Nacional da Anistia Internacional, na cidade de Rimini, no dia 3 de abril de 1981. vol.09, no. 04, Rio de Janeiro, 2016. pp. 2124-2149 2142
} 
Desse modo, a partir de uma perspectiva principiológica, resta perfeitamente fundamentada a decisão do pequeno juiz. Não poderia ser diferente. O princípio contrário à da pena de morte por ele defendido - ainda que sozinho, como adverte ao procurador geral - é um corolário lógico da tradição jurídica iluminista que se encontra inscrita na história institucional (garantista e abolicionista) italiana.

\section{A GUISA DE CONCLUSÃO}

Ao contrário do que se supõe no Brasil, a expressão garantismo remete ao século XVIII, mais especificamente ao pensamento de Francesco Mario Pagano ${ }^{29}$ - e também pode ser encontrada no século XIX, com destaque para a teoria de Benjamin Constant ${ }^{30}$, quando surgem diversos neologismos ${ }^{31}-$, muito antes de ser incorporada ao léxico jurídico, no século XX, especialmente com a difusão da obra de Luigi Ferrajoli: Diritto e ragione $(1989)^{32}$.

No prefácio dessa conhecida obra, uma das mais importantes do século XX no campo da teoria e da filosofia do direito, Norberto Bobbio (1989, p. VII-VIII) observa que a pretensão de seu discípulo é a elaboração daquilo que denomina teoria geral do garantismo, cujo objeto de análise é a antítese entre liberdade e poder que atravessa a história da civilização. Trata-se, com efeito, de uma teoria voltada às bases do estado de direito, isto é, à tutela das liberdades do cidadão frente às várias formas de exercício arbitrário do poder. Não é à toa que, para Ferrajoli, ogarantismo é a outra face do constitucionalismo (TRINDADE, 2012).

Na mesma linha de Beccaria, Kant e Ferrajoli, o pequeno juiz entende que o homem - e, aqui, não há nenhuma razão para excluir o condenado - não deve ser tratado como "meio", ou "coisa", e sim como "fim", como "pessoa". Com isso, ele supera todo e qualquer argumento utilitarista. $\mathrm{O}$ valor da pessoa humana impõe uma

\footnotetext{
${ }^{29}$ Segundo Mario Pagano, o garantismo penal seria, de fato, uma doutrina voltada à limitação da discricionariedade potestativa do juiz (IPPOLITO, 2007).

${ }^{30}$ Nesse sentido, ao definir o verbete constitucionalismo, em seu Dizionario di politica, Matteucci afirma: "Il garantismo, che ha il suo principale teorico in Benjamin Constant, accentua al massimo, in polemica con Rousseau e con l'interpretazione jacobina della volontà generale, l'esigenza di tutelare, sul piano costituzionale, i diritti fondamentali dell'individuo, e cioè la libertà personale, la libertà di stampa, la libertà religiosa e infini l'inviolabilità della proprietá privata" (MATTEUCCI, 1976, p. 205. Registre-se, todavia, que os tradutores da edição brasileira optaram por utilizar o termo teoria das garantias, e não garantismo (MATTEUCCI, 1998, p. 250).

${ }^{31}$ No Dictionnaire de la langue française, de Émile Littré, garantisme é tratado como uma expressão acadêmica empregada no âmbito filosófico-político por Charles Fourier (1772-1837) e seus discípulos. Na obra Le nouvelle monde industriel et societaire (1829), Fourier apresenta o garantismo como um sistema de segurança social voltado à proteção dos mais fracos, fornecendo-lhes as garantias dos direitos vitais através de um plano de reformas referentes tanto à esfera pública quanto às relações privadas (IPPOLITO, 2010). Na Itália, por sua vez, o termo garantismo aparece pela primeira vez na obra Storia del liberalismo in Europa (1925), de Guido De Ruggiero, onde se refere à liberdade política concebida como liberdade do indivíduo em relação com o Estado e perante ele (ANDRÉS IBAÑEZ, 2009.pp. 59-60).

${ }^{32}$ Em entrevista concedida a Gerardo Pisarello e Ramón Suriano, na Universidad Carlo III de Madrid, em 1997, Ferrajoli esclarece: "La palabra garantismo es nueva en el léxico jurídico. Fue introducida en Italia en los años 70 en el ámbito del Derecho Penal. Sin embargo, creo que puede extenderse a todo el sistema de garantías de los derechos fundamentales. En este sentido, el garantismo es sinónimo de Estado constitucional de Derecho" (PISARELLO, 1998, p. 188).
} 
limitação fundamental em relação à qualidade e à quantidade da pena. É sobre esse valor que se funda a proibição à pena de morte, às penas corporais, às penas cruéis, à pena perpétua etc.

Em Portas abertas, essa tradição iluminista, constitucionalista e garantista vem representada através da postura assumida pelo pequeno juiz durante o julgamento. Ele encarna, antecipadamente, o papel de guardião das promessas (GARAPON, 1996), a ser atribuído ao Poder Judiciário apenas na segunda metade do século XX. A ele compete conservar as conquistas civilizatórias e resistir contra toda e qualquer forma de arbitrariedade do poder. E, para isso, como se viu na novela, os princípios mostram-se imprescindíveis.

A decisão do pequeno juiz revela um agir político pautado em princípios garantistas compartilhados por uma comunidade política. Entre esses princípios está a proibição à pena de morte. Eles indicam como deve ser a melhor forma de agir para construir uma boa vida, em suma, fazer o bem, a coisa certa, sem se preocupar com as vantagens e benefícios que tal comportamento possa resultar, mas antes com o modo como se faz as coisas. Tratase de um comportamento virtuoso que deveria orientar toda ação humana ${ }^{33}$.

E isso, como se viu, é o que Dworkin chama decidir por princípio. Em um Estado Democrático de Direito, os agentes políticos - e, aqui, certamente estão incluídos os juízes - tem o dever de agircorretamente, sob pena de perder a legitimidade e a autoridade moral da qual depende seu poder de coerção. É em vista disso que, politicamente, esse Estado não pode atuar de modo pragmaticista, ou consequencialista, abrindo mãos dos princípios, direitos e garantias fundantes da comunidade política.

Retomando e concluindo: imaginem se, em cadeia, todo juiz tratasse de decidir por princípios. Eis o desafio lançado por Sciascia, ainda nos anos 80 , e que pode servir de inspiração à comunidade jurídica nessa triste quadra da História.

\title{
GUARANTEEISM AND LITERATURE: LEONARDO SCIASCIA'S LESSON ON THE ROLE OF PRINCIPLES IN CONSTRUCTION OF DECISIONS
}

\begin{abstract}
This paper addresses one of the major issues concerning court decisions: what is the meaning of "deciding in principle"? In order to do so, assuming the premise that many legal phenomena are best represented by literary narratives, the problem is formulated from the novel Open Doors by Leonardo Sciascia, whose protagonist is a magistrate facing the Fascist Regime by denying death penalty during a controversial case, in the 1930s, of triple homicide, judged in court in Palermo. Thus, based on the methodological principles of Law in Literature and the notion of "models of judges" originally proposed by François Ost, this paper analyzes the representation of the "little judge" and discusses the function of principles in the construction of judgments.
\end{abstract}

\footnotetext{
${ }^{33}$ Nesse mesmo sentido, a leitura de Milone (2005, p. 52), para quem "em defesa desse princípio, mais do que a vida do imputado, o pequeno juiz não se subtrai à responsabilidade do juízo, ao dever da profissão que pratica e à sua dignidade de homem [...] Na sua assunção de responsabilidade, o ele vê o ponto de honra da sua vida, de honra do viver".
} 
Keywords: Law in Literature. Judge models, Leonardo Sciascia. Judicial decision. Principles.

\section{REFERÊNCIAS BIBLIOGRÁFICAS}

ACERBI, Antonio. La chiesa e l'Italia. Per una storia dei loro rapporti negli ultime due secoli. Milano: Vita e Pensiero, 2003.

AGUIAR E SILVA, Joana. A prática judiciária entre direito e literatura. Coimbra: Almedina, 2001.

AMAYA, Amalia. Jueces ejemplares. In: FALCONÍ TRÁVEZ, Diego (Ed.). A medio camino. Intertextos entre la literatura y el derecho. Valencia: Tirant lo Blanch, 2016.p. 85-112.

ANDRÉS IBAÑEZ, Perfecto. Garantismo: una teoría crítica de la jurisdicción. In: CARBONELL, Miguel; SALAZAR, Pedro (Eds.). Garantismo: estudios sobre el pensamiento jurídico de Luigi Ferrajoli. 2. ed. Madrid: Trotta, 2009.

BECCARIA, Cesare. Dei delitti e dele penne. Torino: E. Venturi, 1965.

BERTONI, Raffaele. Salvatore Petrone, giudice e martire. La Repubblica, Roma, 21 aprile 1990, p. 10. Disponível em: http://ricerca.repubblica.it/repubblica/archivio/repubblica/1990/04/21/salvatore-petrone-giudicemartire.html

BOBBIO, Norberto. A era dos direitos. Rio de Janeiro: Elsevier, 2004.

Prefazione. In: FERRAJOLI, Luigi. Diritto e ragione. Teoria del garantismo penale. 8. ed. Roma-Bari: Laterza, 1989.

CALVINO, Italo. Sentiero dei nidi di ragno. Milano: Mondadori, 2006.

Perché leggere i classici. Milano: Mondadori, 1991.

CALVO GONZÁLEZ, José. El escudo de Perseo. La cultura literária del Derecho. Granada: Comares, 2012.

COLUCCELLO, Rino. Challenging the mafia mystique: cosa nostra from the legitimization to denunciation. London: Palgrave Macmillan, 2015.

COUTINHO. Jacinto Nelson de Miranda. O lugar do poder do juiz em "Portas abertas", de Leonardo Sciascia. In: STRECK, Lenio; TRINDADE, André Karam (Orgs.). Os modelos de juiz: ensaios de direito e literatura. São Paulo: Atlas, 2015.p. 211-225.

COVER, Robert. Derecho, narración y violência. Barcelona: Gedisa, 2002.

DIONÍSIO, Maia Amélia. Os movimentos indiciários de/em Leonardo Sciascia. Dissertação de Mestrado. Universidade Federal de Santa Catarina, Programa de Pós-Graduação em Letras, Florianópolis, 2013.

DWORKIN, Ronald. O império do Direito. São Paulo: Martins Fontes, 2014.

Levando os direitos a sério. São Paulo: Martins Fontes, 2002. 
FÁBREGA PONCE, Jorge. Abogados y jueces en la literatura universal. Valencia: Tirant lo Blanch, 2013.

FERRAJOLI, Luigi. Epistemología jurídica y garantismo. México: Fontamara, 2004.

Diritto e ragione. Teoria del garantismo penale. Roma-Bari: Laterza, 1989.

FINUOLI, Marina Di Lello. L'intreccio tra "verità" e "giustizia" nelle opera di Leonardo Sciascia. In: FORTI, G; MAZZUCATO, C; VISCONTI, A. (a cura di). Giustizia e letteratura II. Milano: Vita e Pensiero, 2014. p. 256261.

GARAPON, Antoine. O guardador de promessas: justiça e democracia. Lisboa: Instituto Piaget, 1996.

GRILLI, Luigi. La procedura penale. Guida pratica. Padova: Antonio Milani, 2009. v. I.

HELLER, Hermann. Europa y el fascismo. Granada: Comares, 2006.

HUGO, Victor. O último dia de um condenado. São Paulo: Estação Liberdade, 2010.

IPPOLITO, Dario. Itinerarios del garantismo.Jueces para la democracia, Madrid, n. 69, pp. 6-14, 2010.

El garantismo penal de un ilustrado italiano: Mario Pagano y la lección de Beccaria. Doxa. Cuadernos de

Filosofía del Derecho, Alicante, n. 30, p. 525-542, 2007.

IZZO, Valerio Nitrato. Le "Porte aperte" del giudizio. In: CASUCCI, Felice (a cura di). Diritto di parola. Napoli: Edizioni Scientifiche Italiane, 2010. p. 279-296.

JEAN, Raymond. Victor Hugo. Écrits sur la peine de mort. Textes rassemblés. Paris: Babel, 1992.

LACCHÈ, Luigi (a cura di). Il diritto del Duce. Giustizia e repressione nell'Italia fascista. Roma: Donzelli, 2015.

LAMY, Alberto Sousa. Advogados e juízes na literatura e na sabedoria popular. Lisboa: Ordem dos Advogados, 2001.3.v.

MACALUSO, Emanuele. Sciascia e i comunisti. Milano: Feltrineli, 2010.

MARÍ, Enrique. Derecho y literatura. Algo de lo que sí se puede hablar pero en voz baja. Doxa - Cuadernos de Filosofia del Derecho, Alicante, n. 21, p. 251-87, 1998

MARINO, Pierpaolo Astorina. Il potere e il candore: Leonardo Sciascia, un illuminista sicialiano. In: FORTI, G; MAZZUCATO, C; VISCONTI, A. (a cura di). Giustizia e letteratura II. Milano: Vita e Pensiero, 2014. p. 239255.

MATTEUCCI, Nicola. Constitucionalismo. In: BOBBIO, Norberto; MATTEUCCI, Nicola; PASQUINO, Gianfranco. Dicionário de politica. 11. ed. Brasília: UnB, 1998.

UTET, 1976.

Costituzionalismo. In: BOBBIO, N.; MATTEUCCI, N.; PASQUINO, G. Dizionario di politica. Torino:

MENDOLA, Velania La. Mafia nell'opera di Leonardo Sciascia, avent'anni dale srtagi di Capaci e via D’Amelio. In: FORTI, G; MAZZUCATO, C; VISCONTI, A. (a cura di). Giustizia e letteratura II. Milano: Vita e Pensiero, 2014.p. 198-215. 
MEREU, Italo. La morte como pena. Saggio sulla violenza legale. Roma: Donzelli: 2000.

MEREU, Italo (a cura di). La morte come pena in Leonardo Sciascia: da "Porte aperte" all'abolizione della pena di morte (Collana Quaderni Leonardo Sciascia). Milano: La Vita Felice, 1997.

MILONE, Pietro. Il diritto e le sue metafore. Letteratura e giustizia nell'opera di Sciascia. In: POGLIAGHI, Luigi (a cura di). Giustizia come ossessione (Collana Quaderni Leonardo Sciascia). Milano: La Vita Felice, 2005. p. 3376.

MITTICA, Maria Paola. O que acontece além do oceano? Direito e literatura na Europa. Anamorphosis Revista Internacional de Direito e Literatura, Porto Alegre, v. 1, n. 1, p. 3-36, jan.jun. 2015.

NUSSBAUM, Martha. Emoções racionais. In: TRINDADE, André Karam; GUBERT, Roberta Magalhães; COPETTI NETO, Alfredo (Orgs.). Direito \& Literatura: discurso, imaginário e normatividade. Porto Alegre: Nuria Fabris, 2010.

Il giudizio del poeta. Imagginazione letteraria e vita civile. Milano: Feltrinelli, 1996.

ONOFRI, Massimo. Storia di Sciascia. Roma-Bari: Laterza, 2004.

OST, François. Júpiter, Hercules, Hermes: três modelos de juiz. Juizado da Infância e da Juventude, Porto Alegre, v. 7, n. 17, p. 109-130, jan./mar. 2009.

Contar a lei. As fontes do imaginário jurídico. São Leopoldo: Unisinos, 2005.

Júpiter, Hércules y Hermes. Tres modelos de juez. Doxa - Cuadernos de Filosofia del Derecho, Alicante, n. 14, p. 169-94, 1993.

Jupiter, Hercule, Hermès: trois modèles du juge. In: BOURETZ, Pierre (Dir.) La force du droit. Panorama des débats contemporains, Paris: Esprit, 1991. p. 241-272.

ST, François. Juge-pacificateur, juge-arbitre, juge-entraîneur. Trois modèles de justice. In: OST, François; VAN DE KERCHOVE, Michel; GÉRARD, Philippe (Dir). Fonction de juger et pouvoir judiciaire. Bruxelles: FUSL, 1983, p. 1-70.

PISARELLO, Gerardo. Procesos constituyentes. Caminos para la ruptura democrática Madri: Trotta, 2014.

PISARELLO, Gerardo; SURIANO, Ramón. Entrevista a Luigi Ferrajoli. Isonomía - Revista de Teoría e Filosofia del Derecho, Mexico, n. 9, pp. 187-192, 1998.

POSNER, Richard. Law \& Literature. Cambridge/London: Harvard University Press, 2009.

RODRÍGUEZ, César. La decisión judicial: el debate Hart-Dworkin. 3. ed. Santafé de Bogotá: Siglo del Hombre, 2000.

SANTURBANO, Andrea. Redescobrindo a literatura italiana. In: PETERLE, Patricia; SANTURBANO, Andrea; WATAGHIN, Lucia. (Org.) Literatura italiana traduzida no Brasil: 1900-1950. Rio de Janeiro: Comunità, 2013.

SATTA, Salvatore. Soliloqui e collloqui di um giurista. Padova: CEDAM, 1968.

SAVATTERI, Gaetano. I siciliani. Roma-Bari: Laterza, 2005. 
SBRICCOLI, Mario. Storia del diritto penale e dela giustizia. Scritti editi e inediti (1972-2007). Milano: Giuffrè, 2009, v. 1.

SCARPINATO, Roberto. L'egida impenetrabile: mafia e potere nell'opera di Leonardo Sciascia. In: FORTI, G; MAZZUCATO, C; VISCONTI, A. (a cura di). Giustizia e letteratura II. Milano: Vita e Pensiero, 2014. p. 216238.

SCIASCIA, Leonardo. Opere: narrative, teatro, poesia (a cura di Paolo Squillacioti). Milano: Adelphi, 2012, v. I.

Portas abertas. Rio de Janeiro: Rocco, 1990.

La Sicilia come metafora. Intervista di Marcelle Padovani. Milano: Mondadori, 1979.

SIMONE, Giulia. Il guardasigilli del regime. L'itinerario politico e culturale di Alfredo Rocco. Milano: Franco Angeli, 2012.

STOLZI, Irene. Fascismo e cultura giuridica. Studi Storici. Rivista Trimestrale dell'istituto Gramsci, Roma, n. 1, p. $139-154,2014$

STRECK, Lenio Luiz. Lições de Crítica Hermenêutica do Direito. 2. ed. Porto Alegre: Livraria do Advogado, 2016.

Verdade e consenso: Constituição, hermenêutica e teorias discursivas. 5. ed. São Paulo: Saraiva, 2014

O pós-positivismo e os propalados modelos de juiz (Hércules, Júpiter e Hermes) - dois decálogos necessários. Revista de Direitos e Garantias Fundamentais (FDV), Vitória, v. 7, p. 15-45, 2011.

STRECK, Lenio Luiz; TRINDADE, André Karam. Os modelos de juiz: ensaios de Direito e Literatura. São Paulo: Atlas, 2015.

SZAC, Murielle. Victor Hugo: não à pena de morte. São Paulo: Edições SM, 2010.

TALAVERA, Pedro. Derecho y literatura. Granada: Comares, 2006.

TODOROV, Tzvetan. Tipologia do romance policial. In: TODOROV, Tzvetan. As estruturas narrativas. Trad. de Leyla Perrone-Moisés. São Paulo: Perspectiva, 2006.

Memória del Mal e Tentacion del Bien. Indagación sobre el siglo XX. Barcelona: Península, 2002.

TRINDADE, André Karam; ROSENFIELD, Luis. Réquiem para Ivan Ilitch: O problema da interpretação do direito na literatura de Tolstoi. Revista da Faculdade de Direito - UFPR, Curitiba, v. 60, n. 2, p. 157-176, maio/ago. 2015.

TRINDADE, André Karam; ROSENFIELD, Luis; CALGARO, Júlia. Constituição, absolutismo e liberalismo. Um retrato da magistratura imperial em "O juiz de paz na roça", de Martins Pena. Revista Brasileira de Direito, Passo Fundo, v. 11, p. 126-136, 2015.

TRINDADE, André Karam. Pórcia e os limites da interpretação do direito. Revista Novos Estudos Jurídicos, Itajaí, v. 19, n. 3, p. 755-786, set./dez. 2014.

Garantismo versus neoconstitucionalismo: os desafios do protagonismo judicial em terrae brasilis. In: FERRAJOLI, Luigi; STRECK, Lenio; TRINDADE, André Karam. Garantismo, hermenêutica e (neo)constitucionalismo: um debate com Luigi Ferrajoli. Porto Alegre: Livraria do Advogado, 2012.

TRINDADE, André Karam; GUBERT, Roberta Magalhães. Direito e Literatura: aproximações e perspectivas para se repensar o direito. In: TRINDADE, André Karam; GUBERT, Roberta Magalhães; COPETTI NETO, vol.09, n. 04, Rio de Janeiro, 2016. pp. 2124-2149 2148 
Alfredo (Orgs.). Direito e Literatura: Reflexões Teóricas. Porto Alegre: Livraria do Advogado, 2008. p. 11-66.

VESPAZIANI, Alberto. O poder da linguagem e narrativas processuais. Anamorphosis - Revista Internacional de Direito e Literatura, Porto Alegre, v. 1, n. 1, p. 69-84, jan.-jun. 2015.

VIVA, Samantha Agata. La polemica e l'incognita Courier. Tesi di Dottorato di Ricerca. Università Degli Studi di Catania, Dipartimento di Filosofia Moderna, Catania, 2011.

Trabalho enviado em 31 de março de 2016.

Aceito em 24 de agosto de 2016. 